\title{
The impact of ursodeoxycholic acid treatment on myocardial performance index in the obstetric cholestasis cases
}

\author{
Ertuğrul Karahanoğlu \\ Perinatology Clinic, Balkesir Atatïrk City Hospital, Ballkesir, Turkey
}

\begin{abstract}
Objective: It is asserted that the reason of sudden fetal death in obstetric cholestasis cases is the disruption of fetal cardiac conduction by bile acids. In our study, we aimed to investigate the impact of ursodeoxycholic acid treatment on fetal cardiac functions.

Methods: The prospective cohort study was planned in a tertiary center. The cases diagnosed with obstetric cholestasis were included in the study. Fetal cardiac functions were assessed before and after ursodeoxycholic acid treatment. Fetal myocardial performance index (MPI), AV conduction time (mechanical PR interval), and $\mathrm{E} / \mathrm{A}$ ratios were evaluated.

Results: Ursodeoxycholic acid treatment provides an improvement in the myocardial performance index of right and left ventricles. While the MPI of right ventricle was $0.44 \pm 0.02 \mathrm{~ms}$ before the treatment, it was $0.43 \pm 0.01 \mathrm{~ms}$ after the treatment. These values were and $0.45 \pm 0.02$ $\mathrm{ms}$ and $0.43 \pm 0.02 \mathrm{~ms}$, respectively for the MPI of left ventricle. It was found that AV conduction time was shortened after ursodeoxycholic acid treatment $(116.4 \pm 4.1$ vs. $112.2 \pm 4.1)$. E/A ratios and peripheral and central Doppler resistance indices are affected by the treatment.

Conclusion: The MPI improves after ursodeoxycholic acid treatment. The clinical impact of this improvement on perinatal morbidity and mortality can only be shown by conducting prospective studies with more cases.
\end{abstract}

Keywords: Obstetric cholestasis, myocardial performance index.

\section{Introduction}

The incidence of obstetric cholestasis varies among the studied populations, ranging from $0.3 \%$ to $10 \% \cdot{ }^{[1]}$ It is one of most important complications of sudden fetal

\begin{abstract}
Özet: Ursodeoksikolik asit tedavisinin gebelik kolestazlı olgularda miyokardiyal performans indeksi üzerine etkisi

Amaç: Gebelik kolestazı olgularında ani fetal kaybın nedeni safra asitlerinin fetal kardiyak iletiyi bozması olarak öne sürülmektedir. Biz çalışmamızda ursodeoksikolik asit tedavisinin fetal kardiyak fonksiyonlar üzerine etkisini incelemeyi planlandık.

Yöntem: Prospektif kohort çalışması üçüncü basamak bir merkezde planlandı. Çalışmaya gebelik kolestazı tanısı almış olgular dahil edildi. Fetal kardiyak fonksiyonlar ursodeoksikolik asit tedavisi öncesi ve sonrası değerlendirildi. Fetal miyokardiyal performans indeksi (MPI), AV ileti zamanı (mekanik PR aralığı) ve E/A oranla$\mathrm{r} 1$ incelendi.

Bulgular: Ursodeoksikolik asit tedavisi sağ ve sol ventrikül miyokardiyal performans indeksinde düzelmeye neden olmaktadır. Tedavi öncesi sağ ventrikül MPI $0.44 \pm 0.02 \mathrm{~ms}$ iken tedavi sonrasi $0.43 \pm 0.01 \mathrm{~ms}$ olarak bulundu. Tedavi öncesi sol ventrikül MPI $0.45 \pm 0.02 \mathrm{~ms}$ iken tedavi sonrasi $0.43 \pm 0.02 \mathrm{~ms}$ olarak bulundu. AV ileti zamanının ursodeoksikolikasit tedavisi sonrası kısaldığını tespit edildi (116.4 \pm 4.1'e karşı 112.2 \pm 4.1$)$. E/A oranları, periferik ve santral Doppler dirençleri tedaviden etkilenmemektedir.

Sonuç: Ursodeoksikolik asit tedavisi sonrası MPİ düzelmektedir. Bu düzelmenin klinik olarak perinatal morbidite ve mortalite üzerine etkisi ancak daha fazla hasta ile prospektif çalışmalar yapılarak gösterilebilir.
\end{abstract}

Anahtar sözcükler: Gebelik kolestazı, miyokardiyal performans indeksi.

death. ${ }^{[2]}$ Although complete pathophysiology is not known, increased bile acid is considered to be the reason of the complications. ${ }^{[3,4]}$ Bile acids accumulate in the cardiac conduction system and cause conduction disor-

Correspondence: Ertuğrul Karahanoğlu, MD. Perinatology Clinic, Balıkesir Atatürk City Hospital, Balıkesir, Turkey.

e-mail: ertugrulkarahanoglu1@yahoo.com.tr / Received: January 28, 2019; Accepted: May 15, 2019

Please cite this article as: Karahanoğlu E. The impact of ursodeoxycholic acid treatment on myocardial performance index in the obstetric cholestasis cases. Perinatal Journal 2019;27(1):32-37. doi:10.2399/prn.19.0271005 
ders. ${ }^{[5]}$ The standard treatment for obstetric cholestasis is ursodeoxycholic acid (UDC). Bile acids have arrhythmic effect and UDC antagonizes this effect. ${ }^{[3,6]}$ There are many studies investigating fetal circulation changes in obstetric cholestasis. No change was found before sudden fetal death in peripheral and central Doppler studies. ${ }^{[7]}$ In the recent studies, prolonged fetal cardiac AV conduction time was found in the cases with cholestasis. ${ }^{[8]}$ Myocardial performance index (MPI) is one of the indications of fetal well-being. ${ }^{[9]}$ It is the ratio of the time out of the duration where heart spends for ejection during systole to the ejection time. ${ }^{[10]}$ As the cardiac functions fail, ejection time during systole duration will also get shorter since the contraction strength of myocardium will decrease. MPI fails in the cases with obstetric cholestasis. ${ }^{[1]]}$ Although UDC treatment improves liver function tests, it is not known if it has an impact on cardiac functions or not. In our study, we aimed to investigate the impact of UDC treatment on MPI.

\section{Methods}

The study was designed as a prospective cohort study between April 2018 and December 2018 after obtaining the approval of the ethics committee. The cases with obstetric cholestasis were included in the study. The clinical and laboratory diagnoses of obstetric cholestasis were established. Among the patients referring with itching complaint, the cases without rash and dermatologic condition findings in the physical examination, the cases with itching on hands and feet, increased itching at nights, two times or more increases in ALT and AST values in liver function tests and increased preprandial bile acid $(>10 \mathrm{mlmol} / \mathrm{dl})$ were considered as the cases with obstetric cholestasis. The cases with growth and developmental delay, gestational hypertension, affected alloimmunization, preeclampsia, gestational diabetes, and fetal cardiac anomaly were excluded from the study.

Left MPI was calculated through pulse Doppler flow - time diagram obtained by placing Doppler cursor so as to cover the internal cusp of mitral valve and aortic valve on five-chambered view. The measurements were done by keeping angular correction below 20 degrees. The right ventricular outflow velocity vs. time diagram was obtained by placing Doppler cursor on right ventricular outflow plane. Isovolumic contraction time was considered as the time beginning from the moment when pulse Doppler flow on mitral valve ends up to the moment when aortic ejection starts. Ejection time was considered as the time between the start and end of ejection flow on aortic valve at pulse Doppler. Isovolumic relaxation time was calculated as the time beginning from the end of aortic ejection up until mitral valve is opened (Fig. 1)..$^{[10}$ The measurements were carried out by a researcher using Toshiba Aplio 500 (Canon Medical Systems USA, Inc., Tustin, CA, USA) $4.5-6 \mathrm{~Hz}$ 3D probe. In order to eliminate errors, device speed 5 was used which displays pulse image at maximum width. Valve opening clicks were ignored when conducting the measurements between wave phases. The measurements of the patients were carried out on 3rd pre- and post-treatment days. Since there was only one researcher for each patient, minimum 5 different measurements were done and mean values were calculated. Doppler cursor was placed between left ventricular outflow and anterior cusp of mitral valve to measure $\mathrm{AV}$ conduction time. $\mathrm{E}$ and $\mathrm{A}$ waves were calculated by velocity - time image obtained via mitral valve pulse Doppler. The maximum peaks of first and second waves were calculated as $\mathrm{E}$ and $\mathrm{A}$ waves, respectively. AV conduction time was considered as the time from the start of A wave of mitral valve up to the beginning of ventricular systole (Fig. 1) ${ }^{[12]}$ The pulsatility indices of umbilical and middle cerebral arteries were used for the peripheral and central Doppler flow study.

The Statistics Package for Social Sciences, 18.0 (SPSS Inc., Chicago, IL, USA) was used for statistical calculations. In order to determine the distribution of the data, Kolmogorov-Smirnov and Shapiro-Wilk tests and Q-Q plot were used. The changes of dependent

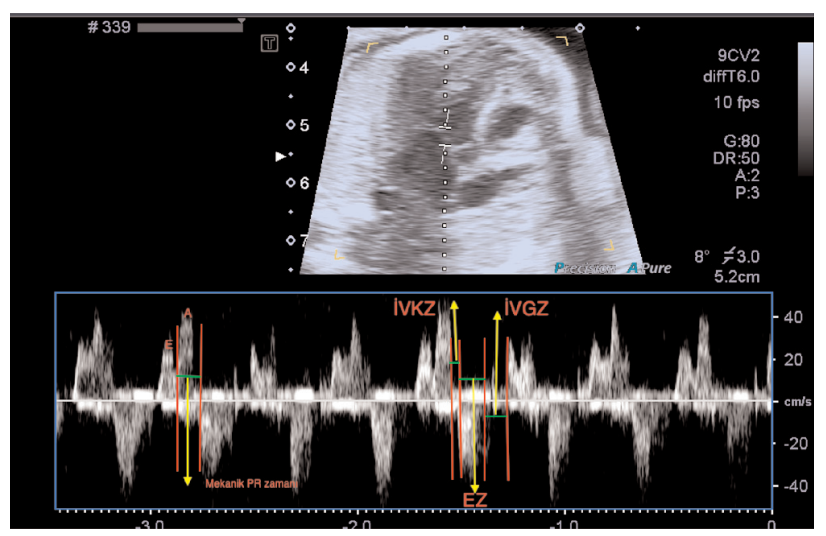

Fig. 1. Measurement of fetal cardiac pulse doppler parameters used in MPI calculation. ET: ejection time; IVCT: isovolumic contraction time; IVRT: isovolumic relaxation time. 
variables before and after the treatment were evaluated by the paired sample $t$ test. $p<0.05$ was considered as significance level. Wilcoxon signed-rank test was used for the data which did not conform to the parametric test conditions. The values were expressed as mean and standard deviation.

\section{Results}

During study period, 12 patients were included in the study. The demographic characteristics are shown in Table 1 . The mean age of the study group was 26.4 . Mean week of gestation was 37 . BMI value of the study group was $25.8 \pm 3.2$. The rate of cesarean section was $66 \%$ which was $30 \%$ higher than the rate of the hospital where this study was conducted. Preprandial bile acid level was $22.1 \mathrm{mmol} / \mathrm{l}$ in the study group.

Cardiac functions before and after UDC treatments are shown in Table 2. It was found that the isovolumic contraction time and isovolumic relaxation time got shortened, and ejection time prolonged after UDC treatment. It was found that UDC treatment shortened MPI (right ventricle $0.44 \pm 0.02 \mathrm{~ms}$ vs. $0.43 \pm 0.01 \mathrm{~ms}$, left ventricle $0.45 \pm 0.02 \mathrm{~ms}$ vs. $0.43 \pm 0.02 \mathrm{~ms}$ ).

The E/A ratio of the right ventricle was $0.72 \pm 0.15$ before the treatment and $0.73 \pm 0.14$ after the treatment, and the E/A ratio of the left ventricle was $0.74 \pm 0.19$ before the treatment and $0.73 \pm 0.18$ after the
Table 1. Demographic characteristics of the study group.

\begin{tabular}{lc}
\hline Age (year) & $26 \pm 4.3$ \\
Delivery week & $37 \pm 3.2$ \\
BMI $\left(\mathrm{kg} / \mathrm{m}^{2}\right)$ & $25.8 \pm 3.2$ \\
C/S ratio (\%) & 66.6 \\
Birth weight (g) & $3045 \pm 346$ \\
Preprandial bile acid (mmol/dl) & $21.2 \pm 8.5$ \\
ALT (IU/L) & $74.8 \pm 32.5$ \\
AST (IU/) & $65.6 \pm 29.4$ \\
\hline
\end{tabular}

BMI: body mass index; C/S: cesarean section.

treatment. It was found that E/A ratio did not change after the treatment. While AV conduction time was $116.4 \pm 4.1 \mathrm{~ms}$ before the treatment, it was $112.2 \pm 4.1 \mathrm{~ms}$ after the treatment. It was found that $\mathrm{AV}$ conduction time got shortened after the treatment.

No change was found in peripheral and central Doppler resistance indices by the treatment. While umbilical artery pulsatility index was $0.81 \pm 0.09$ before the treatment, it was $0.82 \pm 0.07$ after the treatment, MCA artery pulsatility index was $1.71 \pm 0.22$ before the treatment and $1.72 \pm 0.23$ after the treatment.

\section{Discussion}

Obstetric cholestasis is clinically characterized as increase in liver enzymes ( 2 times or more increase in ALT and AST values), increase in preprandial bile acids and itch-

Table 2. Fetal cardiac functions before and after the treatment of ursodeoxycholic acid.

\begin{tabular}{|c|c|c|c|c|}
\hline & Before treatment & After treatment & Change $\Delta t, \Delta I U / d I^{*}$ & p-value \\
\hline RVIVCT (ms) & $34.5 \pm 2.5$ & $33.2 \pm 2.3$ & $-1.3 \pm 1.07$ & 0.00 \\
\hline RVET (ms) & $168.7 \pm 1.5$ & $169.1 \pm 2.5$ & $0.6 \pm 1.9$ & 0.03 \\
\hline RVIVRT (ms) & $41.2 \pm 2.6$ & $39.5 \pm 1.37$ & $-1.6 \pm 1.8$ & 0.04 \\
\hline RVMPI & $0.44 \pm 0.02$ & $0.43 \pm 0.01$ & $-0.015 \pm 0.013$ & 0.02 \\
\hline LVIVCT (ms) & $35.08 \pm 3.8$ & $34.41 \pm 2.3$ & $-0.6 \pm 1.8$ & 0.02 \\
\hline LVET (ms) & $169.75 \pm 2.66$ & $170.25 \pm 2.3$ & $0.5 \pm 2.2$ & 0.02 \\
\hline LVIVRT (ms) & $42.25 \pm 2.09$ & $40.8 \pm 2.06$ & $-0.5 \pm 2.2$ & 0.02 \\
\hline LVMPI & $0.45 \pm 0.02$ & $0.43 \pm 0.02$ & $-0.015 \pm 0.014$ & 0.01 \\
\hline RV E/A ratio & $0.72 \pm 0.15$ & $0.73 \pm 0.14$ & $0.01 \pm 0.01$ & 0.78 \\
\hline LV E/A ratio & $0.74 \pm 0.19$ & $0.73 \pm 0.18$ & $0.01 \pm 0.01$ & 0.82 \\
\hline Mechanical PR interval & $116.4 \pm 4.1$ & $112.2 \pm 4.1$ & $-4.1 \pm 3.2$ & 0.01 \\
\hline UMA PI & $0.81 \pm 0.09$ & $0.82 \pm 0.07$ & $0.01 \pm 001$ & 0.76 \\
\hline MCA PI & $1.71 \pm 0.22$ & $1.72 \pm 0.23$ & 0.010 .001 & 0.89 \\
\hline
\end{tabular}

${ }^{*} \Delta t$ value was given as the mean difference obtained in the paired sample test. It was given as ms and ratio in the parameters where the measurements were millisecond and ratio, respectively. LV: left ventricle; LVET: left ventricular ejection time; LVIVCT: left ventricular isovolumic contraction time; LVIVRT: left ventricular isovolumic relaxation time; LVMPI: left ventricular myocardial performance index; MCA: middle cerebral artery; PI: Pplsatility index, RV: right ventricle; RVET: right ventricular ejection time; RVIVCT: right ventricular isovolumic contraction time; RVIVRT: right ventricular isovolumic relaxation time; RVMPI: right ventricular myocardial performance index; UMA: umbilical artery. 
ing especially on hands and feet at nights. The most significant complication of obstetric cholestasis is sudden fetal death. Fetal death risk increases especially after 37 weeks of gestation, and up-to-date treatment protocols recommend carrying out delivery after 37 weeks of gestation. ${ }^{[13]}$ However, this approach is not based on strong scientific evidence. ${ }^{[13]}$ Although the reason of sudden fetal death is not known certainly, some hypotheses were developed. The most accepted hypothesis is the blockage of cardiac conduction system by bile acids. Previous studies found a prolongation in the fetal cardiac conduction in the cases with obstetric cholestasis. ${ }^{[8]}$ In autopsy studies, bile acid accumulation was found in the fetal cardiac conduction system. ${ }^{[3,14]}$ Molecular studies showed that the basic reason of conduction block in the cases with obstetric cholestasis was bile acids. ${ }^{[15]}$ In cases with obstetric cholestasis, plasma tauric acid level increases. Tauric acid inhibits $\mathrm{L}$ and $\mathrm{T}$ types of $\mathrm{Ca}^{++}$channels, but it also activates the channels which enable $\mathrm{Na}^{+}-\mathrm{Ca}^{++}$change. This causes cardiac conduction slowdown and re-entrant tachycardia in addition to the disruption in the contraction of cardiac myocytes. ${ }^{[6,16]}$ Bile acids inhibit calciummediated conductions and UDC treatment prevents this effect in adult patients. ${ }^{[17]}$ UDC treatment decreases the level of serum bile acids and improves hepatic functions. It increases depolarization in L-type $\mathrm{Ca}^{++}$channels and restores cardiac conduction. ${ }^{[14,17]}$ On the other hand, in addition to the conduction, it also decreases the activation of $\mathrm{p} 53$ and HIF-1 alpha activation which are the factors responsible for tissue damage during the hypoxia in cardiac myocytes. ${ }^{[18]}$ In consistent with the literature, we found in our study that the prolonged fetal AV conduction time associated with the obstetric cholestasis was shortened by UDC treatment. ${ }^{[15]}$

MPI shows both systolic and diastolic cardiac functions. MPI is used to detect cardiac dysfunctions secondary to the disorders in fetal well-being. ${ }^{[19]}$. It displays an increase in conditions which cause disorder in fetal wellbeing. ${ }^{[20-22]}$ MPI was found to increase in obstetric cholestasis. ${ }^{[11]}$ However, the authors of this study did not investigate if the medical treatment improved fetal cardiac functions or not. In our study, we found that the medical treatment improved fetal cardiac functions. UDC treatment provides an improvement in both systolic and diastolic parts of fetal cardiac functions. We found that the treatment increased systolic ejection time and shortened isovolumic relaxation time. Isovolumic contraction is an indication of the diastolic function of ventricles and UDC treatment improves this function. We did not find any change in E/A ratios in our study. $\mathrm{E} / \mathrm{A}$ ratio shows atrium function and it exhibits disorder in case of severe asphyxia. Previous studies reported that E/A ratio did not change in the cases with obstetric cholestasis. ${ }^{[23]}$ It was found that the increase in peripheral Doppler resistance indices, which are the findings of hypoxia and asphyxia, did not fail in the cases with obstetric cholestasis. These findings show that there was a cardiac dysfunction in obstetric cholestasis but this dysfunction did not cause a prenatal asphyxia or hypoxia. It can be considered that primary hypoxia and asphyxia are not the reasons for prenatal loss in obstetric cholestasis. The first expected abnormality can be cardiac conduction disorder. Conduction disorder might lead to diastolic dysfunction and then systolic dysfunction. Fetal cardiac conduction disorder might cause cardiac dysfunction as well as sudden fetal death.

The significance of the improvement that we found has some limitations. The studies performed found many factors affecting the optimal measurement of MPI. ${ }^{[24]}$ These factors cause intermeasurement and intraobserver variations which may affect the result of the study ${ }^{[2-25]}$ The previous studies found interclass correlation coefficient $0.7-0.9$ for MPI. ${ }^{[24-27]}$ Similarly, although we found a shortening in AV conduction time, this finding should be evaluated carefully. AV conduction time exhibits a certain interobserver variability and does not reflect actual PR distance ${ }^{[28-30]}$ Since the mean differences we found are very small, the result should be evaluated carefully. In our study where measurement difference is very small, working with a parameter which has a low interclass correlation coefficient may significantly affect the results. In order to obtain more precise and accurate results, the same measurement should be performed by different researchers, interclass correlation coefficient should be provided and more patients should be studied.

\section{Conclusion}

The fetal MPI improves after ursodeoxycholic acid treatment. However, it is difficult to predict if sonographic recovery causes clinical recovery or not. To answer this question, further prospective studies are required where clinical variables are also evaluated with more patients.

Conflicts of Interest: No conflicts declared. 


\section{References}

1. Geenes V, Williamson C. Intrahepatic cholestasis of pregnancy. World J Gastroenterol 2009;15:2049-66.

2. Reid R, Ivey KJ, Rencoret RH, Storey B. Fetal complications of obstetric cholestasis. Br Med J 1976;1(6014):870-2.

3. Williamson C, Gorelik J, Eaton BM, Lab M, de Swiet M, Korchev Y. The bile acid taurocholate impairs rat cardiomyocyte function: a proposed mechanism for intra-uterine fetal death in obstetric cholestasis. Clin Sci (Lond) 2001;100:363-9.

4. Brites D. Intrahepatic cholestasis of pregnancy: changes in maternal-fetal bile acid balance and improvement by ursodeoxycholic acid. Ann Hepatol 2002;1:20-8.

5. Sheikh Abdul Kadir SH, Miragoli M, Abu-Hayyeh S, Moshkov AV, Xie Q, Keitel V, et al. Bile acid-induced arrhythmia is mediated by muscarinic $\mathrm{M} 2$ receptors in neonatal rat cardiomyocytes. PLoS One 2010;5(3):e9689.

6. Schultz F, Hasan A, Alvarez-Laviada A, Miragoli M, Bhogal $\mathrm{N}$, Wells S, et al. The protective effect of ursodeoxycholic acid in an in vitro model of the human fetal heart occurs via targeting cardiac fibroblasts. Prog Biophys Mol Biol 2016;120:14963 .

7. Zimmermann P, Koskinen J, Vaalamo P, Ranta T. Doppler umbilical artery velocimetry in pregnancies complicated by intrahepatic cholestasis. J Perinat Med 1991;19:351-5.

8. Rodriguez M, Moreno J, Marquez R, Eltit R, Martinez F, Sepulveda-Martinez A, et al. Increased PR interval in fetuses of patients with intrahepatic cholestasis of pregnancy. Fetal Diagn Ther 2016;40:298-302.

9. Crispi F, Hernandez-Andrade E, Pelsers MM, Plasencia W, Benavides-Serralde JA, Eixarch E, et al. Cardiac dysfunction and cell damage across clinical stages of severity in growthrestricted fetuses. Am J Obstet Gynecol 2008;199:254.e1-8.

10. Hernandez-Andrade E, Figueroa-Diesel H, Kottman C, Illanes S, Arraztoa J, Acosta-Rojas R, et al. Gestational-ageadjusted reference values for the modified myocardial performance index for evaluation of fetal left cardiac function. Ultrasound Obstet Gynecol 2007;29:321-5.

11. Henry A, Welsh AW. Monitoring intrahepatic cholestasis of pregnancy using the fetal myocardial performance index: a cohort study. Ultrasound Obstet Gynecol 2015;46:571-8.

12. Strehlow SL, Pathak B, Goodwin TM, Perez BM, Ebrahimi M, Lee RH. The mechanical PR interval in fetuses of women with intrahepatic cholestasis of pregnancy. Am J Obstet Gynecol 2010;203:455.e1-5.

13. Bicocca MJ, Sperling JD, Chauhan SP. Intrahepatic cholestasis of pregnancy: review of six national and regional guidelines. Eur J Obstet Gynecol Reprod Biol 2018;231:180-7.

14. Glantz A, Marschall HU, Lammert F, Mattsson LA. Intrahepatic cholestasis of pregnancy: a randomized controlled trial comparing dexamethasone and ursodeoxycholic acid. Hepatology 2005;42:1399-405.
15. Adeyemi O, Alvarez-Laviada A, Schultz F, Ibrahim E, Trauner $\mathrm{M}$, Williamson $\mathrm{C}$, et al. Ursodeoxycholic acid prevents ventricular conduction slowing and arrhythmia by restoring $\mathrm{T}$ type calcium current in fetuses during cholestasis. PLoS One 2017;12:e0183167.

16. Gorelik J, Shevchuk A, de Swiet M, Lab M, Korchev Y, Williamson C. Comparison of the arrhythmogenic effects of tauro- and glycoconjugates of cholic acid in an in vitro study of rat cardiomyocytes. BJOG 2004;111:867-70.

17. Miragoli M, Kadir SH, Sheppard MN, Salvarani N, Virta M, Wells S, et al. A protective antiarrhythmic role of ursodeoxycholic acid in an in vitro rat model of the cholestatic fetal heart. Hepatology 2011;54:1282-92.

18. Mohamed AS, Hanafi NI, Sheikh Abdul Kadir SH, Md Noor J, Abdul Hamid Hasani N, Ab Rahim S, et al. Ursodeoxycholic acid protects cardiomyocytes against cobalt chloride induced hypoxia by regulating transcriptional mediator of cells stress hypoxia inducible factor 1alpha and p 53 protein. Cell Biochem Funct 2017;35:453-63.

19. Aoki M, Harada K, Ogawa M, Tanaka T. Quantitative assessment of right ventricular function using Doppler tissue imaging in fetuses with and without heart failure. J Am Soc Echocardiogr 2004;17:28-35.

20. Van Mieghem T, Gucciardo L, Done E, Van Schoubroeck D, Graatsma EM, Visser GH, et al. Left ventricular cardiac function in fetuses with congenital diaphragmatic hernia and the effect of fetal endoscopic tracheal occlusion. Ultrasound Obstet Gynecol 2009;34:424-9.

21. Wong ML, Wong WH, Cheung YF. Fetal myocardial performance in pregnancies complicated by gestational impaired glucose tolerance. Ultrasound Obstet Gynecol 2007;29:395400 .

22. Hassan WA, Brockelsby J, Alberry M, Fanelli T, Wladimiroff $\mathrm{J}$, Lees CC. Cardiac function in early onset small for gestational age and growth restricted fetuses. Eur J Obstet Gynecol Reprod Biol 2013;171:262-5.

23. Kurtulmuş S, Gür EB, Öztekin D, Güleç EŞ, Okyay D, Gülhan I. The impact of intrahepatic cholestasis of pregnancy on fetal cardiac and peripheral circulation. J Turk Ger Gynecol Assoc 2015;16:74-9.

24. Lobmaier SM, Cruz-Lemini M, Valenzuela-Alcaraz B, Ortiz JU, Martinez JM, Gratacos E, et al. Influence of equipment and settings on myocardial performance index repeatability and definition of settings to achieve optimal reproducibility. Ultrasound Obstet Gynecol 2014;43:632-9.

25. Welsh AW, Maheshwari P, Wang J, Henry A, Chang D, Crispi F, et al. Evaluation of an automated fetal myocardial performance index. Ultrasound Obstet Gynecol 2016;48:496503.

26. Meriki N, Welsh AW. Development of Australian reference ranges for the left fetal modified myocardial performance index and the influence of caliper location on time interval measurement. Fetal Diagn Ther 2012;32:87-95. 
27. Meriki N, Izurieta A, Welsh A. Reproducibility of constituent time intervals of right and left fetal modified myocardial performance indices on pulsed Doppler echocardiography: a short report. Ultrasound Obstet Gynecol 2012;39:654-8.

28. Glickstein J, Buyon J, Kim M, Friedman D; PRIDE investigators. The fetal Doppler mechanical PR interval: a validation study. Fetal Diagn Ther 2004;19:31-4.
29. Kato Y, Takahashi-Igari M, Inaba T, Sumazaki R, Horigome H. Comparison of PR intervals determined by fetal magnetocardiography and pulsed Doppler echocardiography. Fetal Diagn Ther 2012;32:109-15.

30. Mosimann B, Arampatzis G, Amylidi-Mohr S, Bessire A, Spinelli M, Koumoutsakos P, et al. Reference ranges for fetal atrioventricular and ventriculoatrial time intervals and their ratios during normal pregnancy. Fetal Diagn Ther 2018;44:228-35.

Bu makalenin kullanım izni Creative Commons Attribution-NoCommercial-NoDerivs 3.0 Unported (CC BY-NC-ND3.0) lisansı aracılı̆̆ıly bedelsiz sunulmaktadir. / This work is licensed under the Creative Commons Attribution-NonCommercial-NoDerivs 3.0 Unported (CC BY-NC-ND3.0) License. To view a copy of this license, visit http://creativecommons.org/licenses/by-nc-nd/3.0/ or send a letter to Creative Commons, PO Box 1866, Mountain View, CA 94042, USA. 